\title{
PLANT AVAILABILITY OF TRACE ELEMENTS IN SEWAGE SLUDGE-TREATED SOILS: METHODOLOGY(1)
}

\author{
Giuliano Marchi ${ }^{(2)}$, Luiz Roberto Guimarães Guilherme ${ }^{(3)}$ \& Andrew \\ C. Chang ${ }^{(4)}$
}

\begin{abstract}
SUMMARY
Synthetic root exudates were formulated based on the organic acid composition of root exudates derived from the rhizosphere of aseptically grown corn plants, $\mathrm{pH}$ of the rhizosphere, and the background chemical matrices of the soil solutions. The synthetic root exudates, which mimic the chemical conditions of the rhizosphere environment where soil-borne metals are dissolved and absorbed by plants, were used to extract metals from sewage-sludge treated soils 16 successive times. The concentrations of $\mathrm{Zn}, \mathrm{Cd}, \mathrm{Ni}, \mathrm{Cr}$, and $\mathrm{Cu}$ of the sludge-treated soil were $71.74,0.21,15.90,58.12$, and $37.44 \mathrm{mg} \mathrm{kg}^{-1}$, respectively. The composition of synthetic root exudates consisted of acetic, butyric, glutaric, lactic, maleic, propionic, pyruvic, succinic, tartaric, and valeric acids. The organic acid mixtures had concentrations of 0.05 and $0.1 \mathrm{~mol} \mathrm{~L}^{-1}-\mathrm{COOH}$. The trace elements removed by successive extractions may be considered representative for the availability of these metals to plants in these soils. The chemical speciation of the metals in the liquid phase was calculated; results showed that metals in sludge-treated soils were dissolved and formed soluble complexes with the different organic acidbased root exudates. The most reactive organic acid ligands were lactate, maleate, tartarate, and acetate. The inorganic ligands of chloride and sulfate played insignificant roles in metal dissolution. Except for $\mathrm{Cd}$, free ions did not represent an important chemical species of the metals in the soil rhizosphere. As different metals formed soluble complexes with different ligands in the rhizosphere, no extractor, based on a single reagent would be able to recover all of the potentially plant-available metals from soils; the root exudate-derived organic acid mixtures tested in this study may be better suited to recover potentially plant-available metals from soils than the conventional extractors.
\end{abstract}

Index terms: heavy metals, soil extractant, organic acids, rhizosphere, root exudates.

(1) This work is part of a Thesis written by the first author. Financed by CAPES, CNPq, and FAPEMIG. Received for publication in July 22, 2010 and approved in May 20, 2011.

(2) Researcher at Embrapa Cerrados, Rod. BR 020, km 18, CP 08223, CEP 73310-970 Planaltina (DF), Brasil. E-mail: giuliano.marchi@cpac.embrapa.br

(3) Associate professor at Universidade Federal de Lavras - Depto. de Ciência do Solo, CP 3037, Campus Universitário - CEP 37200 000 Lavras (MG), Brasil. E-mail: guilherm@dcs.ufla.br

(4) Professor Emeritus at University of California, Environmental Sciences Department, Riverside. Geology 2452, Riverside - CA 92521 - USA. E-mail: andrew.chang@ucr.edu 


\title{
RESUMO: DISPONIBILIDADE DE ELEMENTOS-TRACYO PARA PLANTAS EMSOLOS TRATADOS COMLODODE ESGOTO: METODOLOGIA
}

\begin{abstract}
Com base em composições de ácidos orgânicos de exsudatos radiculares obtidos da rizosfera de plantas de milho cultivadas assepticamente, $p H$ da rizosfera e matriz química da solução do solo, extratores sintéticos desses exsudatos foram formulados. Esses extratores, que imitam o ambiente da rizosfera, onde os elementos-traço do solo são dissolvidos e absorvidos pelas plantas, foram usados para extrair elementos-traço de solos 16 vezes sucessivas. A concentração de $\mathrm{Zn}, \mathrm{Cd}, \mathrm{Ni}$, Cr e Cu do solo tratado com lodo de esgoto era de 71,74; 0,21; 15,90; 58,12; e 37,44 $\mathrm{mg} \mathrm{kg}^{-1}$, respectivamente. Os exsudatos radiculares sintéticos foram constituídos pelos ácidos orgânicos acético, butírico, glutárico, lático, maleico, propiônico, pirúvico, succínico, tartárico e valérico. A concentração das misturas de ácidos orgânicos foi de 0,05 e de 0,1 mol $L^{-1}$ de -COOH. Os elementos-traço removidos pelas extrações sucessivas podem ser usados para representar a disponibilidade desses elementos para as plantas nesses solos. A especiação química dos elementos-traço na fase líquida foi calculada. Os resultados mostraram que os elementos-traço em solos tratados com lodo de esgoto foram dissolvidos e formaram complexos solúveis com os diferentes exsudatos radiculares baseados em ácidos orgânicos. Os ligantes orgânicos mais reativos foram lactato, maleato, tartarato e acetato. Os ligantes inorgânicos cloreto e sulfato tiveram papel insignificante na dissolução dos elementostraço. Com exceção de Cd, ions livres não foram importantes espécies químicas de elementostraço na rizosfera do solo. Como diferentes elementos-traço formaram complexos solúveis com diferentes ligantes na rizosfera, nenhum extrator, baseado em apenas um reagente, poderia ser capaz de recuperar todos os elementos-traço potencialmente disponíveis do solo; as misturas de ácidos orgânicos baseados em exsudatos testados neste estudo podem ser mais adequadas para recuperar os elementos-traço do solo potencialmente disponíveis para as plantas do que os extratores convencionais.
\end{abstract}

Termos de indexação: heavy metals, soil extractant, organic acids, rhizosphere, root exudates.

\section{INTRODUCTION}

Around the world, municipal sewage sludge is frequently applied to croplands that constitute the basis of the human food chain. Potentially hazardous trace elements may inadvertently enter human diets as a result of this practice; it is therefore imperative that plant uptake of soil-borne trace elements be evaluated. The plant availability of metals in sludgetreated soils are customarily estimated based on extraction of soil-borne metals with chemical reagents such as DTPA-TEA (mixture of $0.005 \mathrm{M}$ diethylenetriaminepentaacetic acid $+0.005 \mathrm{M}$ triethanol amine (Lopez-Valdivia et al., 2002), EDTA (0.01M ethylenediaminetetraacetic acid sodium salt (Wu et al., 2003), Mehlich I (mixture of $0.05 \mathrm{M} \mathrm{HCl}+$ $0.0125 \mathrm{M} \mathrm{H}_{2} \mathrm{SO}_{4}$; Gartley et al., 2002), Mehlich III (mixture of $0.2 \mathrm{M}$ acetic acid $+0.25 \mathrm{M} \mathrm{NH}_{4} \mathrm{NO}_{3}+0.05 \mathrm{M}$ $\mathrm{NH}_{4} \mathrm{~F}+0.013 \mathrm{M} \mathrm{HNO}_{3}+0.001 \mathrm{M}$ EDTA (Cancela et al., 2002), and ammonium acetate (Ure et al., 1993). Aliquots of soil are equilibrated with the extracting reagents at a consistent soil (weight) to solution (volume) ratio from which the elements recovered from the solution phase are determined. These single-step extraction procedures evolved from diagnosing micronutrient deficiencies of cropland soils by checking the minimal levels of required elements in the soil, below which plant growth would be inhibited. The thermodynamics of metal dissolution was not taken into consideration by this approach to define plant- available metals in soils, and the outcome did not realistically reflect the actually available amount of metals for plant uptake, as only a fraction of the extractable metals was recovered (O'Connor et al., 1984). The dynamics of heavy-metal extraction from sewage sludge-amended Oxisols using the rhizospherederived organic acids and extraction by conventional approaches were compared (Marchi et al., 2009).

The sludge-borne metals are primarily found in solid, low-soluble forms (Candalaria \& Chang, 1997). They would remain as distinctive solid phases in the receiving soils. As the metals dissolve into the soil solution, they are susceptible to adsorption by the nearest soil colloids. Therefore, the soluble forms are locally distributed around the metal solids and the overall metal concentration of the soil solution remains low. Under these circumstances, plant metal absorption would be a short-range mass transfer process that only dissolves metals in the vicinity of roots and under the influence of the rhizosphere are readily available to plants. If soils are plowed for each growing season, in theory, all metals would eventually be exposed to the rhizosphere over time. As the total plant-available metal of soil is fixed, the cumulative removal of metals over time by successive annual crop harvests may be expressed as follows:

$$
\left.M_{t}=M_{0} x e^{-j t}\right)
$$

where $M_{t}$ denotes removal of plant-available metal at $t^{t h}$ years of annual crop harvests, $M_{0}$ is the total plant- 
available metal in the soil, and $j$ the field-based plantavailable metal release rate constant.

Root exudates are the driving force of metal dissolution-related chemical reactions in the rhizosphere. They would increase the plant availability (Romheld \& Marschner, 1986) and enhance the plant uptake (Welch, 1995) of soil-borne metals. Mench \& Martin (1991) found that the root exudates isolated from Nicotiana tabacum L., $N$. rustica L., and Zea mays L. dissolved $\mathrm{Cd}, \mathrm{Cu}, \mathrm{Fe}$, $\mathrm{Mn}, \mathrm{Ni}$, and $\mathrm{Zn}$ in soils in which they were grown. For these three species, the Cd concentrations of plant tissues, which denote the metal uptake per unit of biomass, were proportional to amounts of Cd extracted by the respective root exudates. Krishnamurti et al. (1997) demonstrated that soil Cd may be mobilized by low-molecular-weight organic acids such as acetic, citric, oxalic, fumaric, and succinic acids that were found in root exudates recovered from the rhizosphere.

Organic acids are the primary components of root exudates and by far the most reactive components with soil-borne metals (Abreu et al., 2002). Koo et al. (2006) characterized the organic acids in the rhizosphere where plants grew under aseptic conditions and demonstrated that acetic, butyric, and lactic acids represented 85 to $90 \%$ of the total volume in the rhizosphere and glutaric, maleic, propionic, pyruvic, succinic, tartaric, and valeric acids accounted for the rest. The composition and volume of organic acids produced were consistent throughout the growing season. The presence of sewage sludge in soils did not affect the composition of organic acids in root exudates, but increased the volume of organic acids produced rather significantly.

The plant-available metals in soils would therefore be the fraction of soil-borne metals extractable by root exudates, which can be recovered by exhaustively extracting the soil-borne metals with root exudates. However, at certain times roots produce rather small volumes of exudates that are difficult to recover in situ. For practical purposes, synthetic root exudates may be formulated based on the organic acid compositions and concentrations, rhizosphere $\mathrm{pH}$, and ionic strength of the soil solution (Koo et al., 2008) to evaluate plant availability of metals. Assuming first order reaction kinetics, the metal removed with each successive extraction would be proportional to the plant-available metals remaining in the soil. Koo et al. (2008) postulated that the total plant-available metals of the soils $\left(M_{0}\right.$ in $\left.\mathrm{mg} \mathrm{kg}^{-1}\right)$ may be expressed mathematically so that the cumulative metal removal after the $x^{\text {th }}$ successive extraction (i.e. $M_{x}$ in $\mathrm{mg} \mathrm{kg}^{-1}$ ) is:

$$
M_{x}=M_{0} x\left(1-e^{-k x}\right)
$$

where $x$ denotes the number of successive extractions and $k$ the metal extraction rate constant. $M_{x}$ in Eq. 2 is obtained by summing up the recovered metal; $x$ is known; $M_{0}$ and $k$ can be obtained by fitting the data to equation 2 by nonlinear regression. The value of $M_{0}$ in equation 1 should mathematically equal $M_{0}$ obtained through equation 2 , i.e., the plant-available metal of the soil.

The reactions of dissolved metals and the synthetically formulated root exudates were examined in successive extractions of metals recovered from a sewage sludge-treated soil, and it was demonstrated that the plant-available metal content of the soils may be estimated by the measured amounts of metals extracted.

\section{MATERIALS AND METHODS}

The experimental field from which the sewagesludge treated soil were sampled was located in Jaguariúna, São Paulo State, Brazil ( $22^{\circ} 41$ ' S, $\left.47^{\circ} \mathrm{W}\right)$. For 5 years, sewage sludge from the Franca Sewage Sludge Treatment Station (São Paulo State, Brazil) was applied with a total cumulative load of $150 \mathrm{Mg} \mathrm{ha}^{-1}$ and annual rates of $24,26,30,35$, and $34 \mathrm{Mg} \mathrm{ha}{ }^{-1}$, respectively. Sewage sludge was surfaceapplied and then incorporated in the top $20 \mathrm{~cm}$ of the soil. The characteristics of the soil and sewage sludge were described by Bettiol et al., 2006. Six months after sludge application, the soils were collected from the area, aliquots of soil were dissolved using the USEPA Method 3052 by microwave digestion (USEPA, 1996) with $\mathrm{HCl}-\mathrm{HNO}_{3}-\mathrm{HF}$. The soil concentrations of $\mathrm{Zn}, \mathrm{Cd}, \mathrm{Ni}, \mathrm{Cr}$, and $\mathrm{Cu}$ were 71.74, $0.21,15.90,58.12$ and $37.44 \mathrm{mg} \mathrm{kg}^{-1}$, respectively.

\section{Soil Saturation Extracts}

The saturation extract of a soil denotes that the soil is extracted with the maximum volume of water without significantly changing the soluble ion concentration in the soil solution. Rhoades (1996) elaborated a fundamental concept and detailed the analytical protocols of soil saturation extraction. In this case, the chemical matrix of soil solutions was defined by preparing three replicates of soil saturation extracts according to Rhoades (1996) and determining $\mathrm{pH}\left(\mathrm{pH}_{\mathrm{H} 2 \mathrm{O}}\right)$, electrical conductivity (EC), and concentrations of soluble ions of the extracts. Aliquots saved for the cation analysis were acidified by adding $1 \% \mathrm{HNO}_{3}$ and the concentrations of $\mathrm{Ca}^{2+}, \mathrm{Mg}^{2+}, \mathrm{K}^{+}$, $\mathrm{Na}^{+}$, and $\mathrm{Al}^{3+}$ were determined by ICP-optical emission spectroscopy. The anion concentrations (i.e. $\mathrm{NO}_{3}$, $\mathrm{Cl}^{-}, \mathrm{SO}_{4}{ }^{2-}$, and $\mathrm{PO}_{4}{ }^{3-}$ ) were determined by ion chromatography (Table 1). The ionic strength of the soil solution was calculated accordingly (Griffin \& Jurinak, 1973; Table 2).

\section{Extraction of soil-borne metals}

\section{Synthetic root exudates}

The organic acid composition of the synthetic root exudates was adjusted to the composition of organic acids found by Koo et al. $(2006,2008)$ (Table 3) in root 
Table 1. Compounds in the saturation extract of the control and sewage sludge-treated soils ${ }^{(1)}$

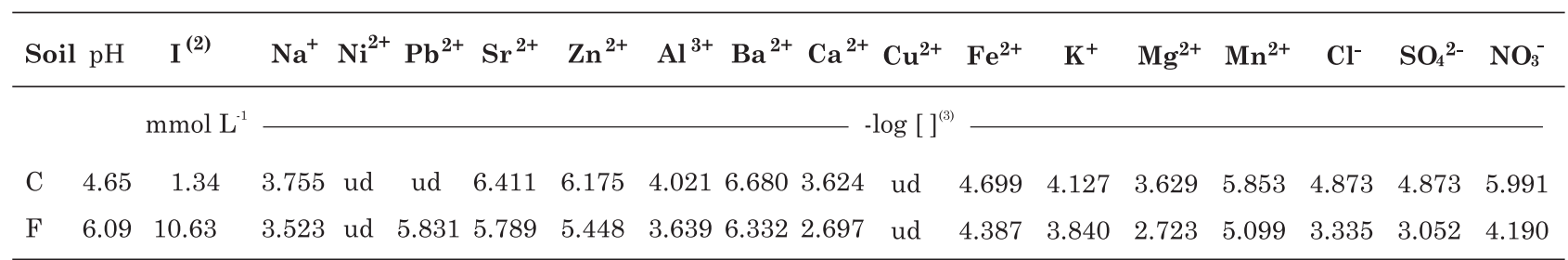

(1) Data represent mean value of three samples. ${ }^{(2)}$ Ionic strength (I) calculated from the data in the table. ${ }^{(3)}$ [ ] denotes concentration of a given species in $\mathrm{mol} \mathrm{L}^{-1}$ in the extracts, respectively. ud: undetected values, below detection limits. C: control soil; F: sewage sludge-treated soil.

Table 2. Properties of saturation extracts of the control and sewage sludge-treated soils ${ }^{(1)}$

\begin{tabular}{|c|c|c|c|c|c|c|c|c|}
\hline Soil & Sum cations $s^{(2)}$ & $\mathrm{EC} \times 10$ & $\mathrm{I}(\mathrm{EC}) \times 1000^{(3)}$ & {$[\mathrm{Ca}+\mathrm{Mg}]^{(3)}$} & {$[\mathrm{Na}+\mathrm{K}]^{(3)}$} & $\mathrm{CaSO}_{4}{ }^{(4)}$ & $\mathrm{NaCl}^{(4)}$ & $I^{(5)}$ \\
\hline & $\operatorname{mmol}_{c} \mathrm{~L}^{-1}$ & $\mathrm{dS} \mathrm{dm} \mathrm{m}^{-1}$ & 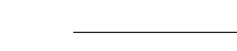 & 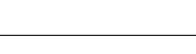 & $-\operatorname{mmol}_{\mathrm{c}} \mathrm{L}^{-1}$ & 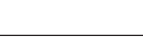 & 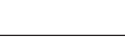 & 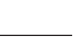 \\
\hline $\mathrm{C}$ & 1.195 & 1.41 & 1.795 & 0.47 & 0.25 & 0.5 & 0.25 & 2.25 \\
\hline $\mathrm{F}$ & 8.248 & 7.03 & 8.928 & 3.90 & 0.44 & 4.0 & 0.50 & 16.5 \\
\hline
\end{tabular}

exudates of maize (Zea mays L.) grown in sewage sludge-treated media. The formulation was based on the mole fractions of the organic acid functional group, - $\mathrm{COOH}$, found in the root exudates, and the ionic strength determined by major cations and anions that composed the background matrices of the soil solution (Tables 2 and 3). Uren \& Reisenauer (1988), Evans et al. (1995), and Bermond et al. (1998) reported that the $\mathrm{pH}$ of the rhizosphere was between 4 and 5 , which does not significantly change the solubility of a metal. The $\mathrm{pH}$ of the synthetic root exudates was adjusted to and maintained at 4.8 during the extractions (Koo et al., 2008).

\section{Plant-available metals}

Aliquots of 1,5 g of the sewage sludge-treated soil (air-dried basis) were mixed with the synthetic root exudates, i.e. the root exudate- based organic acid mixture (RE-OAs) described in the above section, in $50 \mathrm{~mL}$ teflon test tubes at a weight:volume ratio of 1:20. The soil:reagent ratio was according to conventional soil metal extraction procedures (Ure et

Table 3. Composition of synthetic root exudates (RE-OAs) $)^{(1)}$

\begin{tabular}{|c|c|c|c|c|}
\hline Organic acid & Molecular weight & Formula & -COOH Functional group & Mole fraction of $-\mathrm{COOH}$ \\
\hline Acetic & 60.05 & $\mathrm{C}_{2} \mathrm{H}_{4} \mathrm{O}_{2}$ & 1 & 0.2998 \\
\hline Butyric & 88.11 & $\mathrm{C}_{4} \mathrm{H}_{8} \mathrm{O}_{2}$ & 1 & 0.2183 \\
\hline Glutaric & 132.12 & $\mathrm{C}_{5} \mathrm{H}_{8} \mathrm{O}_{4}$ & 2 & 0.0042 \\
\hline Lactic & 90.08 & $\mathrm{C}_{3} \mathrm{H}_{6} \mathrm{O}_{3}$ & 1 & 0.3823 \\
\hline Maleic & 116.07 & $\mathrm{C}_{4} \mathrm{H}_{4} \mathrm{O}_{4}$ & 2 & 0.0439 \\
\hline Propionic & 74.08 & $\mathrm{C}_{3} \mathrm{H}_{6} \mathrm{O}_{2}$ & 1 & 0.0104 \\
\hline Pyruvic & 88.06 & $\mathrm{C}_{3} \mathrm{H}_{4} \mathrm{O}_{3}$ & 1 & 0.0004 \\
\hline Succinic & 118.09 & $\mathrm{C}_{4} \mathrm{H}_{6} \mathrm{O}_{4}$ & 2 & 0.0063 \\
\hline Tartaric & 150.09 & $\mathrm{C}_{4} \mathrm{H}_{6} \mathrm{O}_{6}$ & 2 & 0.0334 \\
\hline Valeric & 102.13 & $\mathrm{C}_{5} \mathrm{H}_{10} \mathrm{O}_{2}$ & 1 & 0.0010 \\
\hline
\end{tabular}

(1) Adapted from Koo et al. (2006, 2008) 
al., 1993; Lopez-Valdivia et al., 2002; Gartley et al., 2002; Cancela et al., 2002; Wu et al., 2003). The tubes were capped and rotated end over end at $2 \mathrm{rpm}$ for 24 or $48 \mathrm{~h}$ at $25^{\circ} \mathrm{C}$ using a rotary mixer. The mixtures were periodically adjusted to maintain a $\mathrm{pH}$ of $4.8 \pm$ 0.1. The RE-OAs concentrations were set at 0.05 and $0.1 \mathrm{~mol} \mathrm{~L}^{-1}$ of $-\mathrm{COOH}$. To keep the strength of the extracting solution consistent, one percent $v / v$ of chloroform was used to inhibit microbial activity during the extraction. Each treatment combination was replicated four times and each soil sample was extracted 16 successive times.

At the end of each extraction, the suspensions were centrifuged for $20 \mathrm{~min}$ at $8,000 \mathrm{rpm}$ to separate the solution and solid phases. The solution phase was decanted and passed through a $0.45 \mu \mathrm{m}$ filter with a PVFD membrane (Millex, Millipore) into $50 \mathrm{~mL}$ flasks. The filtrates were acidified with $1 \%(\mathrm{v} / \mathrm{v})$ concentrated $\mathrm{HNO}_{3}$ and the $\mathrm{Cd}, \mathrm{Zn}, \mathrm{Cr}, \mathrm{Cu}$, and Ni contents in all extractants were determined using a Perkin-Elmer AAnalyst 800 atomic absorption spectrometer (PerkinElmer, Bodenseewerk, Germany) using flame for $\mathrm{Zn}$ and graphite furnace for analysis of $\mathrm{Cd}, \mathrm{Cr}, \mathrm{Cu}$, and $\mathrm{Ni}$.

Trace-metal grade chemicals were used whenever available to prepare reagents without further purification. The prepared reagents, such as the synthetic root exudates, were then checked for metal impurity. For all metal determinations, quality control and quality assurance protocols of the National Institute of Standards and Technology (NIST) were used and Standard Reference Material (SRM) 1640 of trace elements in natural water and the reference material Lab Performance Check Standard 1 (LPC1-100/500) from SPEX. To minimize a carry-over of error, the calculations of dilutions and preparation of check and calibration standards were carried out by different persons. The performance check standard was analyzed after calibration. If the measured concentration of the element differed by $\pm 10 \%$ from the certified value, the calibration curve was rejected and calibration repeated. The NIST SRM 1640 (reference) was analyzed along with each determination batch. If the measured concentration exceeded $\pm 10 \%$ of the certified value, the failed batch was rejected and the analysis repeated. In addition, the analysis of a sample was repeated when the relative difference between replicates was greater than $\pm 10 \%$.

The cumulative metal removal with respect to the number of extractions was fitted to Eq. 2, where $M_{x}$ stands for the cumulative metals removed $\left(\mathrm{mg} \mathrm{kg}^{-1}\right)$ of $x$ successive extractions; $M_{0}$ is the total removable, therefore plant-available, metal of the soil $\left(\mathrm{mg} \mathrm{kg}^{-1}\right)$; $k$ is the extraction rate $\left(\varepsilon^{-1}\right)$; and $x$ is the number of extractions from 1 through 16 , as the soils were successively extracted 16 times. The cumulative metal removal of 16 extractions, $M_{16}$, approached $M_{0}$ (i.e. $M_{16} \approx M_{0}$ ).

To examine the reactions of metals and organic acids, the metals in solution phase were chemically speciated by to the computer algorithms of software package Visual Minteq (Evans et al., 1995).

\section{RESULTS AND DISCUSSION}

\section{Chemical properties of sewage-treated soil}

The chemical properties of the soils had been altered by sludge applications (Table 1). Comparing chemical properties of the control and sludge-treated soils, the soil $\mathrm{pH}$ rose from 4.65 in the control treatment to 6.09 in the sewage sludge treatment. There were across-the-board increase in soluble ion concentrations in the soil solution when the soil was treated with sewage sludge for five years. As a result, the ionic strength of soil solution rose approximately eight-fold, from $1.34 \mathrm{mmol} \mathrm{L}^{-1}$ in the control soil to $10.63 \mathrm{mmol} \mathrm{L}^{-1}$ in the sewage sludge-treated soil. This change in the background matrix would have significant effects on metal dissolution from the solid phase and the formation of metal ion pairs in the soil solution, which in turn would affect the plant availability of soil-borne metals.

\section{Plant-available metals}

Plant-available metals can be estimated by extracting metals from the soils in question using the synthetically formulated root exudates (Koo et al, 2008). Mathematically, the cumulative metal concentrations extracted in 16 successive extractions gradually converged as indicated by Eq. 2 (Figure 1). The cumulative root exudates extractable $\mathrm{Zn}, \mathrm{Cd}, \mathrm{Ni}$, $\mathrm{Cr}$, and $\mathrm{Cu}$ by root exudates were $54-70,12-17,9$ $14,0.3-0.8$, and $2-4 \%$ of the total metals in the sludge-treated soils. Based on the percentage of metals extracted from sludge-treated soil, Zn seems to be most available to plants. The plant availability of $\mathrm{Cd}, \mathrm{Ni}$, and $\mathrm{Cu}$ would be approximately one or two orders of magnitude lower. The $\mathrm{Cr}$ in sludge-treated soils appeared not readily available to plant uptake.

The rhizosphere conditions, especially the organic acid strength of the root exudates were expected to remain stable throughout the growing season (Bermond et al., 1998). Generally, the strength of organic acids of the rhizosphere varied over the growing season from 0.05 to $0.1 \mathrm{~mol} \mathrm{~L}^{-1}$ of $-\mathrm{COOH}$ (Koo, 2006). Had the $\mathrm{X}$-axis of all five diagrams in figure 1 been plotted on the same scale ( $\mathrm{mol}$ of $\mathrm{COOH}$ instead of number of extractions), the cumulative metal extracted in 16 successive extractions would be shown to be similar and in the same order of magnitude, regardless of whether the organic acid strength of the synthetic root exudates was 0.05 or $0.1 \mathrm{~mol} \mathrm{~L}^{-1}$. The extraction reached equilibrium in 24 hours and extracting the soils for 48 hours did not significantly affect the results.

\section{Speciation of solution-phase metals}

Metals in the solution phase provided information on how the metals are dissolved in the rhizosphere 


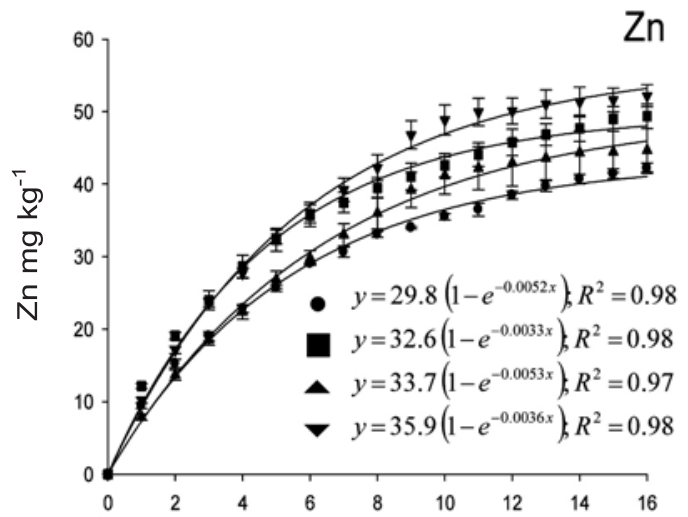

- $50 \mathrm{mmol} \mathrm{L}^{-1} ; 24 \mathrm{~h}$

- $100 \mathrm{mmol} \mathrm{L}^{-1} ; 24 \mathrm{~h}$

- $50 \mathrm{mmol} \mathrm{L}^{-1} ; 48 \mathrm{~h}$

$\checkmark 100 \mathrm{mmol} \mathrm{L}^{-1} ; 48 \mathrm{~h}$
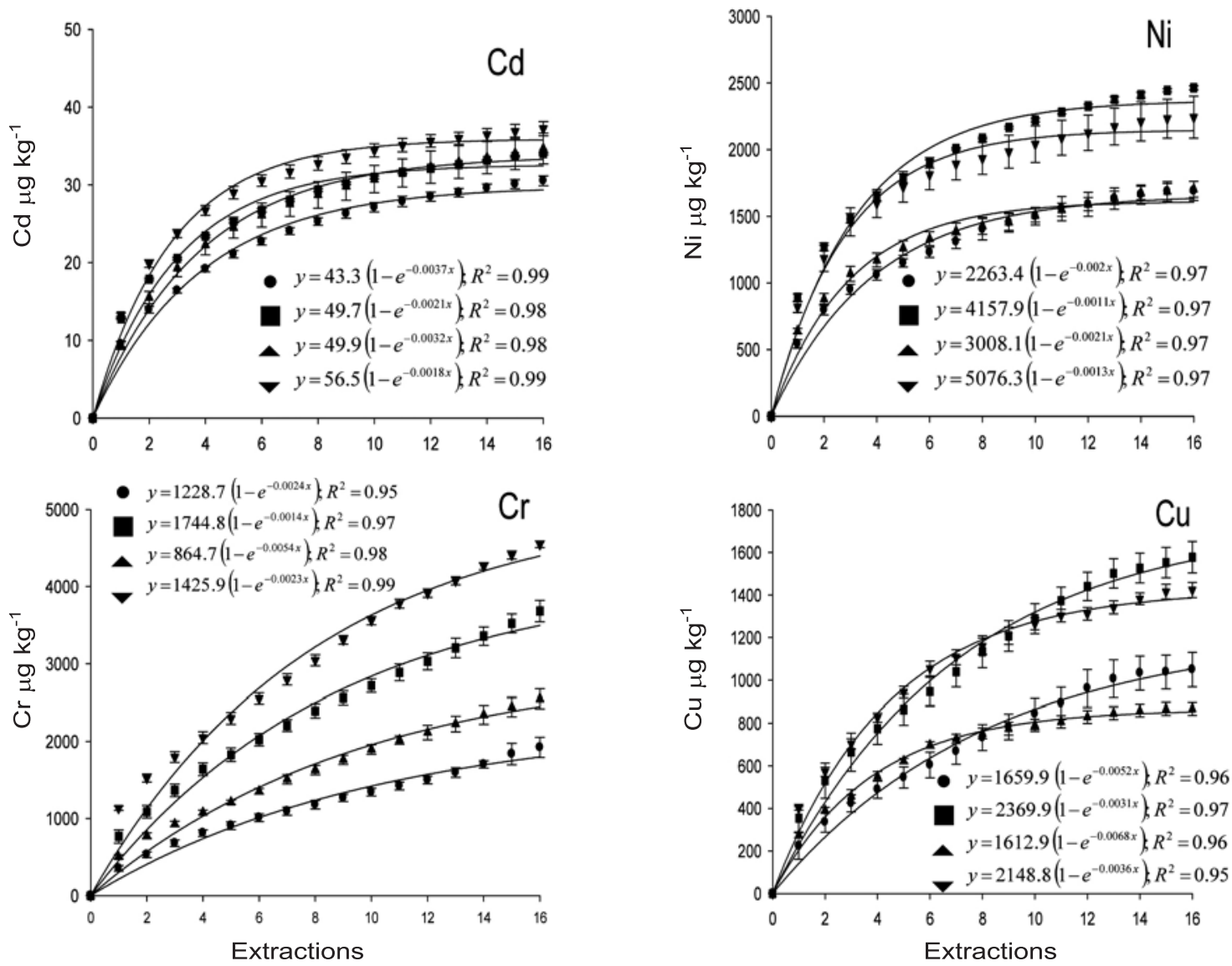

Figure 1. Successive extractions for 24 or 48 hours of $\mathrm{Zn}, \mathrm{Cd}, \mathrm{Ni}, \mathrm{Cr}$, and $\mathrm{Cu}$ from a sewage sludge-treated soil by organic acid mixtures $\left(50\right.$ and $\left.100 \mathrm{mmol} \mathrm{L}^{-1}\right)$.

(Table 2). In the synthetic root exudates (i.e., the metal extracting reagent) the organic acids would be the most prominent ligands to form complexes with metals in the solution phase. It is indicative that during the extractions the metal dissolutions were controlled by kinetics and were not limited by the lack of reactive chemical species as since over $90 \%$ of the dominant ligands such as the acetate, butyrate, lactate, sulfate, and chloride did not form complexes. Only in successive extractions do the plant-available metals be recovered. It is also indicative that the available metals would slowly release in the soil and be taken up by growing plants over a long period of time.
The complexes formed were metal-specific. Ninety seven percent of the $\mathrm{Zn}$ in the solution phase would form organo-metallic complexes with lactate and less than $2 \%$ of the dissolved $\mathrm{Zn}$ was in the free ionic form. Nickel, $\mathrm{Cr}$, and $\mathrm{Cu}$ also formed strong organometallic complexes with maleate, tartarate, and acetate in addition to lactate. Only 19, 1.5 and $7.4 \%$ of the $\mathrm{Ni}, \mathrm{Cr}$, and $\mathrm{Cu}$, respectively, were in free ion form. When strong organo-metallic complexes were formed, the inorganic ion pairs with sulfate and chloride were insignificant. Cadmium in the free ion form accounted for $48 \%$ of total $\mathrm{Cd}$ in solution phase with $28 \%$ of the total forming complexes with acetate. 
Acetate has been commonly used as extracting reagent of plant-available metal, however, based on the data presented in table 4 , acetate did not react effectively with the metals in the soils. RE-OA was far more effective in dissolving the plant-available metals in the soils. The organo-metal complexes formed were not affected by the higher organic acid concentration of extracting solution (Mench \& Martin, 2001; Gustafsson, 2004).

Table 4. Chemical species of metals successively extracted by the synthetic root exudates of $0.1 \mathrm{~mol} \mathrm{~L}^{-1}$ organic acid strength in back ground matrix of $4 \mathrm{mmol} \mathrm{L}^{-1}$ of $\mathrm{CaSO}_{4}+0.5 \mathrm{mmol} \mathrm{L}^{-1}$ of $\mathrm{NaCl}$

\begin{tabular}{|c|c|c|c|c|c|c|c|c|}
\hline Species & Free ion & Cd & $\mathrm{Zn}$ & $\mathrm{Ni}$ & $\mathrm{Cr}$ & $\mathrm{Cu}$ & $\mathbf{C a}$ & $\mathrm{Na}$ \\
\hline & $\%$ total & & & & $\%$ & & & \\
\hline Acetate & 97.3 & 27.7 & 0.4 & 3.8 & 0.7 & 9.4 & 0.8 & 1.9 \\
\hline Butyrate & 99.5 & - & 0.2 & 0.4 & - & 4.8 & 0.5 & - \\
\hline Glutarate & 98.3 & 0.3 & - & 0.1 & - & 0.1 & 1.6 & - \\
\hline Lactate & 97.2 & 13.1 & 96.6 & 44.9 & 42.5 & 63.7 & 1.3 & - \\
\hline Propionate & 99.6 & 0.4 & - & 0.1 & - & 0.3 & 0.4 & - \\
\hline Succinate & 94.9 & 0.3 & - & 0.1 & - & 0.3 & 1.4 & 3.7 \\
\hline Tartarate & 71.3 & 3.9 & 0.7 & 8.3 & 0.2 & 10.6 & 14.3 & 13.9 \\
\hline Maleate & 85.2 & 1.5 & 0.2 & 21.3 & 54.6 & 2.7 & 8.3 & 5.1 \\
\hline $\mathrm{Cl}^{-}$ & 100 & 0.8 & - & - & - & - & - & - \\
\hline $\mathrm{SO}_{4}^{2-}$ & 100 & 5.3 & 0.2 & 1.8 & - & 0.8 & 6.8 & 0.7 \\
\hline Free ion & - & 46.7 & 1.6 & 19.1 & 1.5 & 7.4 & 61.7 & 98.0 \\
\hline
\end{tabular}

Based on the calculation using software package Visual Minteq (Gustafsson, 2004); species with less than $0.1 \%$ were excluded.

\section{CONCLUSIONS}

The results of this experiment showed that metals in sludge-treated soils are dissolved and form soluble complexes with different root exudate- based organic acids. The most reactive organic acid ligands with $\mathrm{Cd}, \mathrm{Zn}, \mathrm{Ni}, \mathrm{Cr}$, and $\mathrm{Cu}$ in the soils are lactate, maleate, tartarate, and acetate. The inorganic ligands such as chloride and sulfate played minor roles in forming the ion pairs. Except for $\mathrm{Cd}$, free ions were not an important chemical species of metal in the soil solutions of rhizosphere. As each metal reacted differently with metal dissolving ligands in the rhizosphere, no single chemical soil extracting reagent would be able to recover all of the potentially plantavailable metals of the soils. From this point of view, the RE-OA would be the most realistic and appropriate soil extracting solution to assess plant-available metals in the soil.

\section{LITERATURE CITED}

BERMOND, A.; YOUSFII, I. \& GHESTEM, J.P. Kinetic approach to the chemical speciation of trace metals in soils. Analyst, 123:785-789, 1998.
BETTIOL, W.; CAMARGO, O.A.; GALVÃO, J.A.H. \& GHINI, R. Impacto ambiental do uso agrícola do lodo de esgoto: Descrição do estudo. In: BETTIOL, W. \& CAMARGO, O., eds. Lodo de esgoto: Impactos ambientais na agricultura. Jaguariúna, Embrapa Meio Ambiente, 2006. p.17-23.

ABREU, C.A.; ABREU, M.F. \& BERTON, R.S. Análise química de solo para metais pesados. In: ALVAREZ V., V.H.; SCHAEFER, C.E.G.R.; BARROS, N.F.; MELLO, J.W. \& COSTA, L.M., eds.Tópicos em ciência do solo. Viçosa, MG, Sociedade Brasileira de Ciência do Solo, 2002. p.645-692.

CANCELA, R.C.; ABREU, C.A. \& PAZ-GONZALEZ, A. DTPA and Mehlich-3 micronutrient extractability in natural soils. Comm. Soil Sci. Plant Anal., 33:2879-2893, 2002.

CANDALARIA, L.M. \& CHANG, A.C. Cadmium activities, solution speciation, and solid phase distribution of $\mathrm{Cd}$ in cadmium nitrate and sewage sludge-treated soil systems. Soil Sci., 162:722-732, 1997.

EVANS, L.J.; SPIERS, G.A. \& ZHA, G. Chemical aspects of heavy metal solubility with reference to sewage sludge amended soils. Inter. J. Environ. Anal. Chem., 59:291302,1995 .

GARTlEY, K.L.; SIMS, J.T.; OLSEN, C.T. \& CHU, P. Comparison of soil test extractants used in Mid-Atlantic United States. Comm. Soil Sci. Plant Anal 33:873-895, 2002.

GRIFFIN, R.A. \& JURINAK, J.J. Estimation of ion activity coefficients from electrical conductivity of natural aquatic systems and soil extracts. Soil Sci., 116:26-30, 1973.

GUSTAFSSON, J.P. Visual Minteq, ver. 2.21. Stockholm, Land and Water Resources Engineering, 2004.

KOO, B.J.; CHANG, A.C.; PAGE, A.L.; GRANATO, T.C. \& DOWDY, R.H. Assessing long-term plant availability of biosolids-borne heavy metals accumulated in cropland soils. In: RESIDUALS AND BIOSOLIDS 2008; TRADITIONS, TRENDS, AND TECHNOLOGIES, Philadelphia, 2008. Proceedings of the Water Environment Federation - Specialty Conferences. Philadelphia, 2008. p.57-76.

KOO, B.J.; CHANG, A.C.; CROWLEY, D.E. \& PAGE, A.L. Characterization of organic acids recovered from rhizosphere of corn grown on Biosolids treated media. Comm. Soil Sci. Plant Anal., 37:871-887, 2006.

KRISHNAMURTI, G.S.R.; CIESLINSKI, G.; HUANG, P.M. \& van REES, K.C.J. Kinetics of cadmium release from soils as influenced by organic acids: Implication in cadmium availability. J. Environ. Qual., 26:271-277, 1997.

LOPEZ-VALDIVIA, L.M.; FERNANDEZ, M.D.; OBRADOR, A. \& ALVAREZ, J.M. Zinc transformations in acidic soil and zinc efficiency on maize by adding six organic zinc complexes. J. Agric. Food Chem., 50:1455-1460, 2002.

MARCHI, G.; GUILHERME, L.R.G.; CHANG, A.C. \& NASCIMENTO, C.W.A. Heavy metals extractability in a soil amended with sewage sludge. Sci. Agric., 66:643-649, 2009. 
MENCH, M. \& MARTIN, E. Mobilization of cadmium and other metals from two soils by root exudates of Zea mays L., Nicotiana tabacum L. and Nicotiana rustica L. Plant Soil, 132:187-196, 1991.

O'CONNOR, G.A.; O'CONNOR, C. \& CLINE, G.R. Sorption of cadmium by calcareous soils: Influence of solution composition. Soil Sci. Soc. Am. J., 48:1244-1247, 1984.

RHOADES, J.D. Salinity: Electrical conductivity and total dissolved solids. In: BARTELS, J.M., ed. Methods of soil analysis: Chemical methods. Madison, Soil Science Society of America, 1996. Part 3. p.417-435.

ROMHELD, V. \& MARSCHNER, H. Evidence for the existence of a specific uptake system for iron phytosiderophores in roots of grasses. Plant Physiol., 80:175-180, 1986.

URE, M.; THOMAS, R. \& LITTLEJOHN, D. Ammonium acetate extracts and their analysis for the speciation of metal ions in soils and sediments. Inter. J. Anal. Chem., 51:65-84, 1993.
UREN, N.C. \& REISENAUER, H.M. The role of root exudates in nutrient acquisition. Adv. Plant Nutr., 3:79-114, 1988.

USEPA. Method 3052: Microwave assisted acid digestion of silicious and organically based matrices. Washington, United States Environmental Protection Agency, 1996.

WELCH, R.M. Micronutrient nutrition of plants. Crit. Rev. Plant Sci., 14:49-82, 1995.

WU, L.H.; LUO, Y.M.; CHRISTIE, P. \& WONG, M.H. Effects of EDTA and low molecular weight organic acids on soil solution properties of a heavy metal polluted soil. Chemosphere, 50:819-822, 2003. 